\title{
A New Platyrrhine from the Middle Miocene of La Venta, Colombia, and the Phyletic Position of Callicebinae
}

\author{
Masanaru Takai ${ }^{1}$, Federico Anaya $^{2}$, Hisashi Suzuki ${ }^{3}$, \\ Nobuo Shigehara ${ }^{1}$, and Takeshi Setoguchi ${ }^{4}$ \\ ${ }^{1}$ Primate Research Institute, Kyoto University, Inuyama \\ ${ }^{2}$ Museo Nacional de Historia Natural, La Paz, Bolivia \\ ${ }^{3}$ Kyoto University Museum, Kyoto \\ ${ }^{4}$ Department of Geology, Kyoto University, Kyoto
}

(Received June 4, 2001; accepted October 1, 2001)

\begin{abstract}
A new platyrrhine, Miocallicebus villaviejai gen. et sp. nov., from the middle Miocene of La Venta (Colombia) is described. The specimen consists of a right maxillary fragment preserving a root of $\mathrm{M}^{1}$, a complete $\mathrm{M}^{2}$, and a fragmentary $\mathrm{M}^{3}$. Miocallicebus is included in the Callicebinae on the basis of $\mathrm{M}^{2}$ structure, but it differs from extant Callicebus in its much larger size and the position of the pterygoid process. Morphological analysis of $\mathrm{M}^{2}$ structure suggests that the Callicebinae are more closely related to the pitheciinae than to other platyrrhine taxa, supporting the phylogenetic reconstruction proposed by recent molecular biological studies. The Callicebus-lineage is likely to have appeared by the middle Miocene age in the La Venta fauna.
\end{abstract}

Keywords: Miocallicebus villaviejai, Callicebinae, Platyrrhini, Colombia, Middle Miocene

\section{Introduction}

Since the 1940s many platyrrhine fossils have been recovered from the middle Miocene sediments of La Venta, the Tatacoa desert, Southern Colombia (Fig. 1): Stirtonia tatacoensis (including "Kondous"; Stirton, 1951; Hershkovitz, 1970; Setoguchi et al., 1981) and S. victoriae (Kay et al., 1987); Neosaimiri fieldsi (including "Laventiana annectens", Stirton, 1951; Rosenberger et al., 1991; Takai, 1994; Nakatsukasa et al., 1997); Cebupithecia sarmientoi (Stirton, 1951; Meldrum and Kay, 1997); Micodon kiotensis (Setoguchi and Rosenberger, 1985); Mohanamico hershkovitzi (Luchterhand et al., 1986); Aotus dindensis (Setoguchi and Rosenberger, 1987); Lagonimico conclutatus (Kay, 1994), Patasola magdalenae (Kay and Meldrum, 1997); and Nuciruptor rubicae (Meldrum and Kay, 1997).

Corresponding author: Masanaru Takai

Primate Research Institute, Kyoto University

41 Kanrin, Inuyama, Aichi 484-8506, Japan

E-mail: takai@pri.kyoto-u.ac.jp 


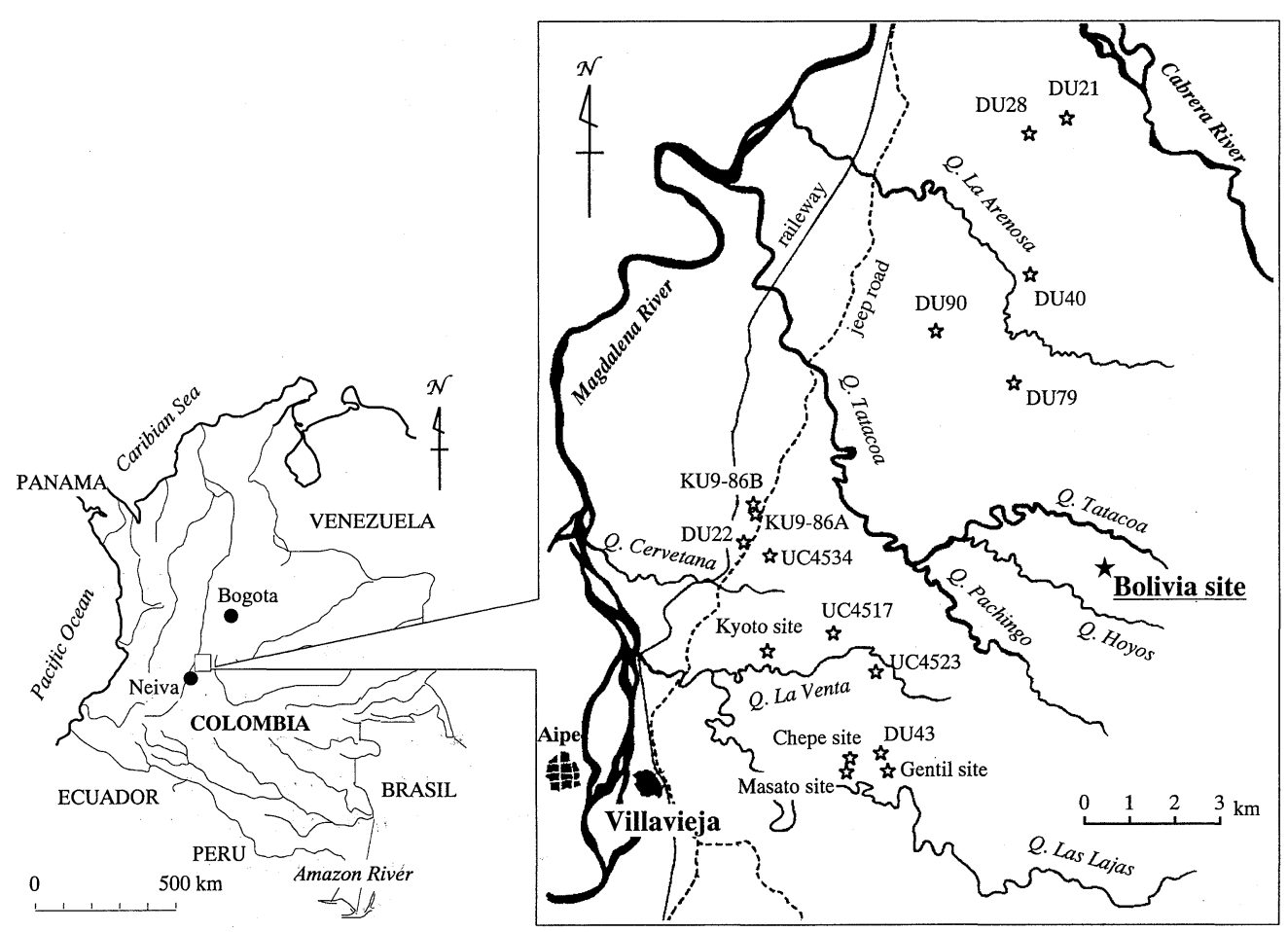

Figure 1. Index map of La Venta, southern Colombia, showing the localities of fossil primates. UC: University of California; KU: Kyoto University; DU: Duke University. The site names, such as Kyoto, Chepe, Masato, Gentil, and Bolivia sites, are of the Kyoto University locality numbers.

Compared with the early/middle Miocene forms of Patagonia, these La Venta platyrrhines are notable in exhibiting very modern aspects, that have remarkable similarities to extant platyrrhine taxa, indicating a phylogenetic relationship with living platyrrhine clades (e.g. Fleagle et al., 1997; Fleagle and Kay, 1997; Fleagle, 1999): Stirtonia and Neosaimiri are regarded as the ancestral taxa of living howler monkeys (Alouatta) and squirrel monkeys (Saimiri), respectively (e.g. Stirton, 1951; Hershkovitz, 1970; Rosenberger, 1979); Cebupithecia and Nuciruptor are thought to be ancestral sakis (pitheciines) (Stirton, 1951; Meldrum and Kay, 1997); Aotus dindensis is considered as the middle Miocene species of Aotus (and/or Mohanamico, see Luchterhand et al., 1986; Setoguchi and Rosenberger, 1987; Kay, 1990; Rosenberger et al., 1990); Micodon, Lagonimico and Patasola are included in the Callitrichinae (Setoguchi and Rosenberger, 1985; Kay, 1990; Kay and Meldrum, 1997).

On the other hand, the phylogenetic relationships of living platyrrhine monkeys have been long discussed by many researchers. At present three main monophyletic groups, callitrichines (including Callithrix, Cebuella, Saguinus, Leontopithecus, and 
Callimico), pitheciines (including Pithecia, Cacajao, and Chiropotes), and atelines (including Alouatta, Ateles, Brachyteles, and Lagothrix) are generally recognized by most researchers. However, the relationships among these three groups and the phyletic positions of other four genera (Aotus, Callicebus, Saimiri, and Cebus) have been variously reconstructed by many morphological studies. For instance, Rosenberger $(1979,1981)$ and Ford (1986) regarded pitheciines and atelines as more closely related to each other than to callitrichines, while Kay (1990) considered atelines and callitrichines as more closely related to each other than to pitheciines.

Among these morphological studies, the arrangements of the remaining four genera are in even more disagreement: Rosenberger $(1979,1981)$ placed Cebus and Saimiri most closely to the callitrichines, and Aotus and Callicebus with the pitheciines; Ford (1986) regarded Saimiri as a relative of the Aotus-Callicebus clade, and Cebus as a stem group of the platyrrhine radiation (or that Cebus and Saimiri possibly form a clade, see Ford, 1986); Kay (1990) considered Callicebus and Cebus as two outgroups of the callitrichines, atelines and pitheciines, linking Saimiri with callitrichines, and Aotus with atelines and callitrichines as a trichotomous clade.

Recently, many molecular biological studies have proposed phylogenetic trees of living platyrrhines (e.g. Schneider et al., 1993; Harada et al., 1995; Porter et al., 1995; Horovitz and Meyer, 1995; Porter et al., 1997a, 1997b; Barroso et al., 1997; Horovitz, 1999). Although all these studies also recognize three main monophyletic groups (the atelines, callitrichines, and pitheciines) in living platyrrhines, it is notable that all these studies propose a Callicebus-pitheciines sister relationship, and regard Saimiri, Cebus and Aotus as most closely related to the callitrichines. The fossil record of the Callicebus lineage would help to verify these hypothetical phylogenetic trees: that is, the relationship of Callicebus to the pitheciines and/or Aotus, or other possibilities.

Since 1977, paleontological expeditions by INGEOMINAS (Instituto de Investigaciones en Geociencias, Mineria y Quimica, Colombia) and the Primate Research Institute of Kyoto University (Japan) have recovered many primate fossils from the middle Miocene deposits in La Venta (Fig. 1). During the 1997 field season, a fossil specimen of a new primate was recovered by surface collection. The specimen is a right maxillary fragment preserving a root of $\mathrm{M}^{1}$, a complete $\mathrm{M}^{2}$, and a badly damaged M3. The overall morphology of this specimen suggests that it may be closely related to Callicebus, titi monkeys.

\section{Terminology and Abbreviations}

In order to avoid confusion in terminology we basically adopt the classification of Primates proposed by Fleagle (1999). Abbreviations used in this paper are as follows: IGM, INGEOMINAS; IGM-KU, INGEOMINAS-Kyoto University; DU, Duke 
University; UCMP, University of California Museum of Paleontology; KUPRI, Primate Research Institute, Kyoto University.

\section{Systematic Paleontology}

Order Primates Linnaeus, 1758

Infraorder Platyrrhini Geoffroy, 1812

Family Atelidae Gray, 1825

Subfamily Callicebinae

Miocallicebus villaviejai gen. et sp. nov. (Fig. 2)

Type specimen. IGM-KU 97001, a right maxillary fragment preserving the anterior base of the pterygoid process and a partial root of $\mathbf{M}^{1}$, complete $\mathbf{M}^{2}$, and poorly preserved $\mathrm{M}^{3}$.

Age and locality. Middle Miocene (Laventan Land Mammal Age, Madden et al., 1996). Discovered at the "Bolivia Site" (316'53”N; 75¹1'40”W) of Los Mesones, on the right side of Quebrada (= small river) Los Hoyos, Tatacoa desert, Huila Department, Colombia (Fig. 1). Just above the "Tatacoa Sandstone Beds" of the La Victoria Formation of Guerrero (1997), from which several radioisotopic dates have been obtained: $13.78 \pm 0.08 \mathrm{Ma}, 13.34 \pm 0.41 \mathrm{Ma}, 12.65 \pm 0.26 \mathrm{Ma}$, and $12.49 \pm 0.11 \mathrm{Ma}$ (Guerrero, 1997; Fig. 3).

Etymology. "Mio" from the Miocene age, and "callicebus" from Callicebus, extant titi monkeys, for the resemblance between them. "Villavieja" is a name of the village where the type specimen was discovered.

Generic diagnosis. Medium size primate with three molars. Upper molars are very low crowned, and $\mathrm{M}^{2}$ is square in occlusal outline with a distinct hypocone. A paracone and metacone are situated very buccally, and a protocone and metacone are connected by the postprotocrista-metaloph. $\mathrm{M}^{3}$ is rather obliquely oriented to
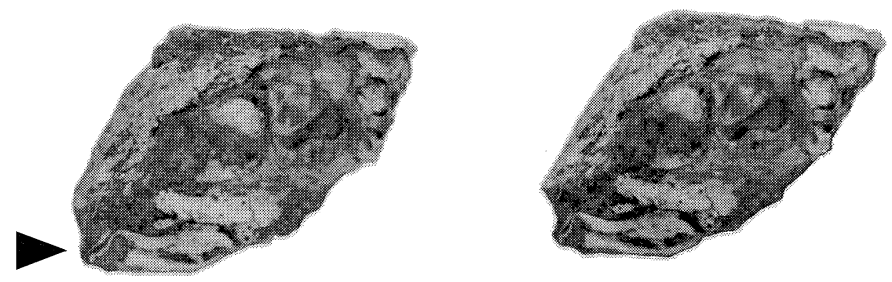

\section{$\|I\| \Pi\|\Pi\|$}

Figure 2. Miocallicebus villaviejai, IGM-KU 97001, the type specimen (a right maxillary fragment preserving $\mathrm{M}^{2}$ and fragments of $\mathrm{M}^{1}$ and $\mathrm{M}^{3}$, steropair). The arrow indicates the base of the pterygoid process. Scale bar $=1 \mathrm{~cm}$. 


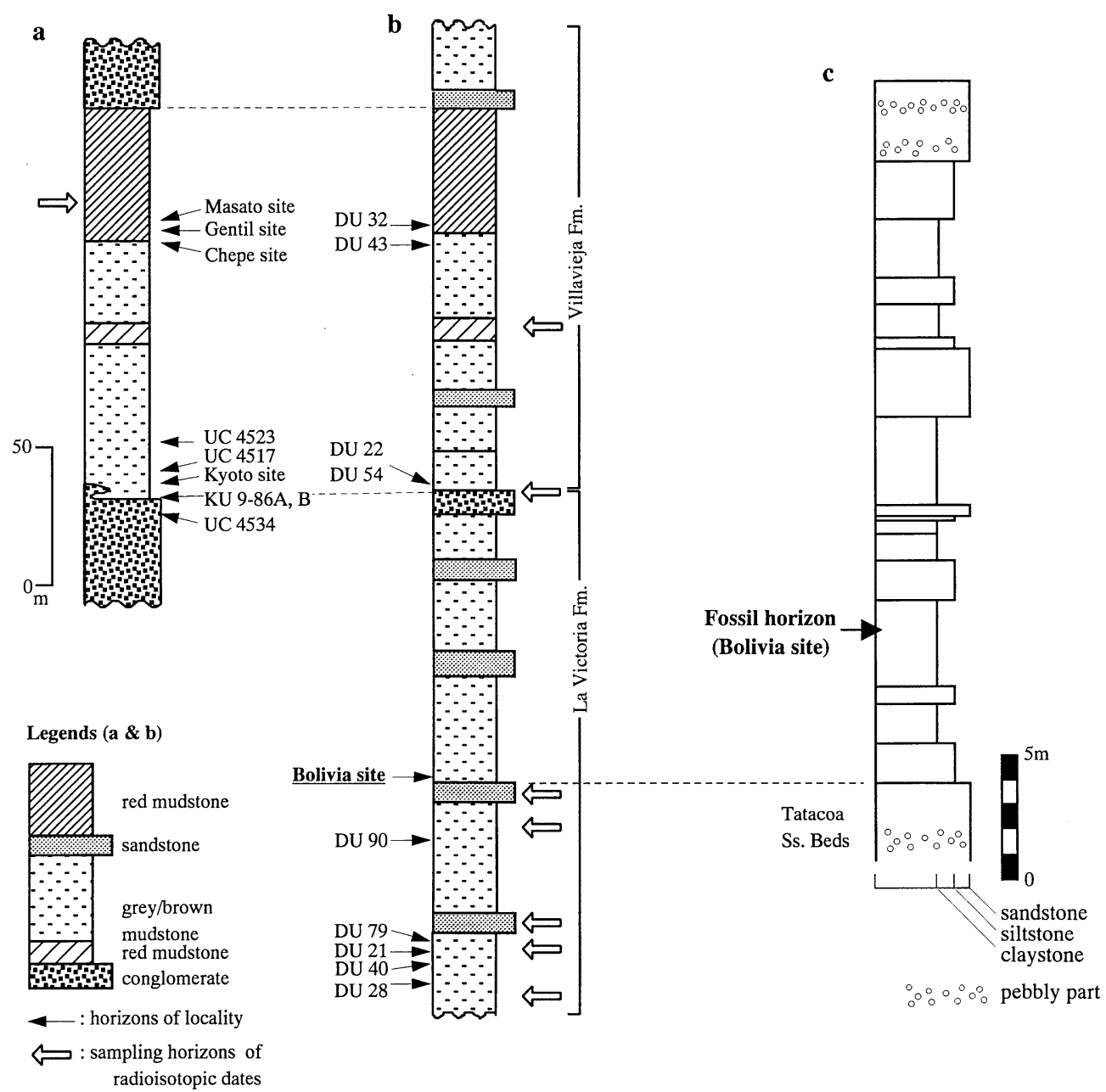

Figure 3. Schematic columnar sections (a: Takai et al., 1992; b: Guerrero, 1997) of the La Venta sediments and a detailed columnar section of the Bolivia site (c), showing the horizons of fossil specimens described in the text. Abbreviations are same as in Fig. 1.

the tooth row. Upper molars decrease in size from $\mathrm{M}^{1}>\mathrm{M}^{2} \gg \mathrm{M}^{3}$. Differs from all extant and extinct callitrichines in the combination of having three molars and a well-developed hypocone on $\mathrm{M}^{2}$. Differs from atelines in having a nearly square occlusal $\mathrm{M}^{2}$ outline, a distinct lingual cingulum on $\mathrm{M}^{2}$, and no deep lingual groove on $\mathrm{M}^{2}$. Differs from Saimiri and Neosaimiri in having a square-outlined $\mathrm{M}^{2}$ with a large hypocone. Differs from Cebus in having a nearly continuous lingual cingulum and thin enamel layer on $\mathrm{M}^{2}$. Differs from aotines in having a lingual cingulum and in lacking a deep lingual groove on $\mathrm{M}^{2}$. Differs from pitheciines in having a distinct crista obliqua, a small but distinct lingual cingulum, no enamel crenula- 
tion, and a "not-evenly worn" wear pattern on $\mathrm{M}^{2}$. Differs from extant Callicebus in its much larger size and in having a pterygoid process more medially situated. Differs from Branisella in having a square-outlined $\mathbf{M}^{2}$ with a well-developed hypocone. Differs from all early-middle Miocene platyrrhines from Patagonia and Chile, such as Dolichocebus, Soriacebus, Carlocebus, in having a more squareoutlined $\mathrm{M}^{2}$ with a buccally situated paracone and metacone. Differs from Antillothrix in having a more rectangular occlusal outline and a less developed lingual cingulum on $\mathbf{M}^{2}$. Differs from Paralouatta in having a protocone more lingually situated and a less developed lingual cingulum on $\mathrm{M}^{2}$, and in having a more medially situated pterygoid process.

Specific diagnosis. As for genus.

\section{Description and Comparison with Platyrrhine Monkeys}

The $\mathrm{M}^{2}$ of Miocallicebus is much larger than that of extant Callicebus, nearly equal to that of extant Cebus or slightly smaller than that of Ateles (mesiodistal

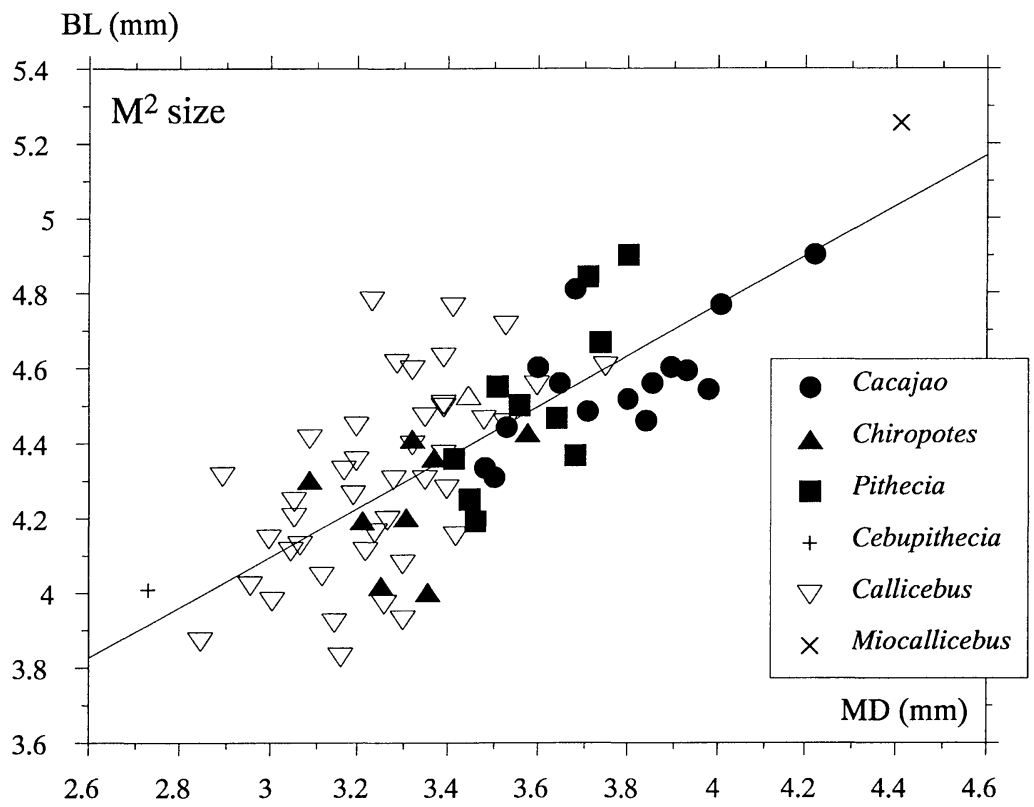

Figure 4. Bivariate plots of the M2 of several extant and extinct platyrrhines. Note that the M2 of Miocallicebus is much larger than that of the pitheciines and Callicebus. MD, mesiodistal length (mm); BL, buccolingual width (mm). Cacajao includes C. calvus and C. melanocephalus. Chiropotes includes $C$. albinosus and $C$. satanus. Pithecia includes $P$. irrorata, $P$. monachus and P. pithecia. Callicebus includes $C$. brunneus, C. caligatus, C. cupreus, C. hoffmannsi, C. moloch, C. ornatus, C. personatus and C. torquatus. 

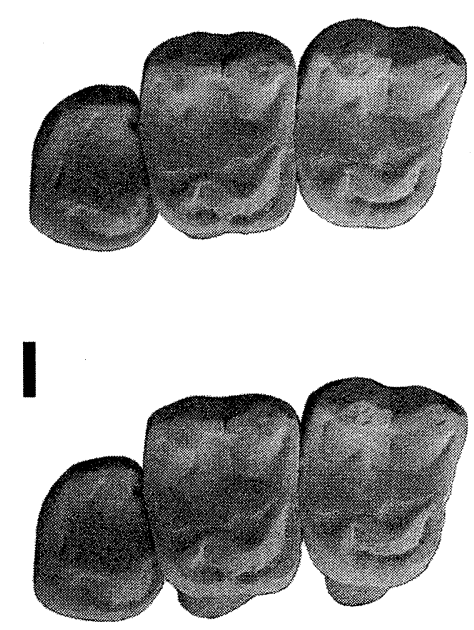

으

Figure 5. Scanning electron micrographs (steropair) of Miocallicebus villaviejai (a, IGM-KU 97001), a new specimen of fossil aotine discovered in the La Venta fauna (b, IGM-KU 98003, right $\mathrm{M}^{2-3}$ ), Cebupithecia sarmientoi (c, UCMP 38762, left $\mathrm{M}^{1-2}$ ), and Callicebus moloch (d, KUPRI 700, right $\mathrm{M}^{1-3}$ ). Scale bars $=1 \mathrm{~mm}$.

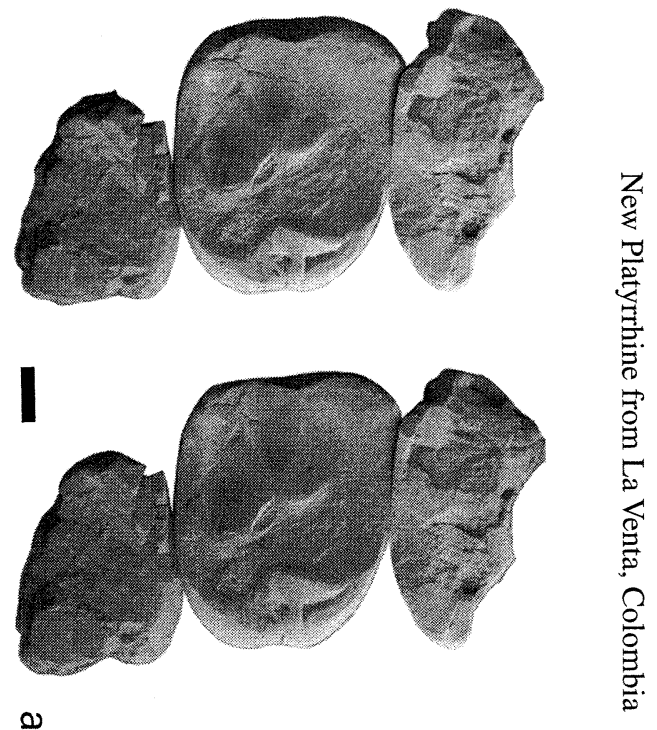


length, $4.41 \mathrm{~mm}$ and buccolingual width, $5.25 \mathrm{~mm}$; Figs. 4 and 5). The outline of $\mathrm{M}^{2}$ is nearly square in occlusal view, and slightly smaller than $\mathrm{M}^{1}$ but much larger than $\mathrm{M}^{3}$. Two buccal cusps, the paracone and metacone, are so marginally situated that there is neither a stylar shelf nor a buccal cingulum. The hypocone is situated more lingually than is the protocone. The lingual half of $\mathrm{M}^{2}$ is very worn exposing a dentine area at the positions of the protocone and hypocone. A small but distinct lingual cingulum runs from the lingual face of the protocone through to the hypocone. The crista obliqua (= the metaloph and postprotocrista) is well developed. The distal fovea, which is formed by the crista obliqua and the distal cingulum, is moderately deep. The $\mathrm{M}^{3}$, which is badly damaged by weathering, is likely to be rather oval in occlusal outline and implanted slightly obliquely to the tooth row.

Among living three-molared platyrrhines, Callimico and Saimiri have a more triangular $\mathrm{M}^{2}$ with a poorly developed hypocone (Fig. 6d, j). Alouatta has highly specialized upper molars with strongly developed shearing crests (Fig. 6c), and other atelines (Ateles, Brachyteles, Lagothrix) have more roundish-outlined upper molars with deep lingual grooves (= lingual cleft, Rosenberger, 1979) (Fig. 6b). In Cebus the outline of $\mathrm{M}^{2}$ is parallelogram-like rather than square, and the upper molars hardly ever show such a sharp wear ridge of the buccal cones as in Miocallicebus, probably because of their thick enamel layer (Fig. 6i).

The morphological resemblance in $\mathrm{M}^{2}$ structure between Miocallicebus and extant Aotus (rectangular outline, a well developed crista obliqua, the paracone and metacone situated rather buccally, and a poorly developed lingual cingulum, Fig. 6h) suggest a possible close relationship between them. The close relationship between extant Callicebus and Aotus has previously been proposed by some researchers (Rosenberger, 1979, 1981; Ford, 1986). In the La Venta fauna a fossil owl monkey, Aotus dindensis, was discovered in the lowest part of the Villavieja Formation in the 1980s (locality number, 9-86A; see Figs. 1 and 3; Setoguchi and Rosenberger, 1987; Kay, 1990; Rosenberger et al., 1990). The type specimen of this species consists of a left mandibular corpus preserving $\mathrm{I}^{1}-\mathrm{M}^{3}$ and a right maxillary fragment preserving a fragment of $\mathrm{M}^{3}$, so it is impossible to make a direct comparison between Miocallicebus and A. dindensis. During the 1998 and '99 field seasons, however, new maxillary and mandibular specimens of an aotine monkey were discovered near the Masato site (Fig. 2; Takai et al., in prep). All these specimens (IGM-KU 98001-008, 99001003) most probably belong to the same individual, because they were collected from a very small spot and appear almost the same in dental size without overlap of tooth class. The lower dentition of this new material is nearly identical to that of $A$. dindensis except in its larger size, so it could be referred to a new species of fossil Aotus (Takai et al., in prep). Compared with $\mathrm{M}^{2}$ of Miocallicebus, the $\mathrm{M}^{2}$ of this new fossil aotine (IGM-KU 98003, Fig. 5b) is much smaller in size, is buccolingually waisted by deep buccal and lingual grooves, preserves no lingual cingulum, and its 

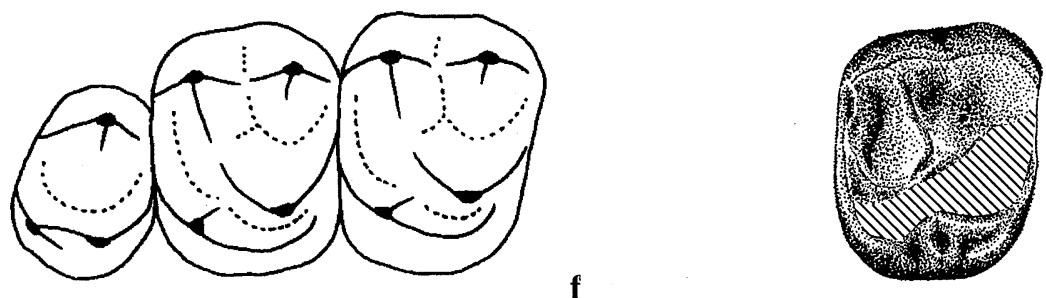

f a
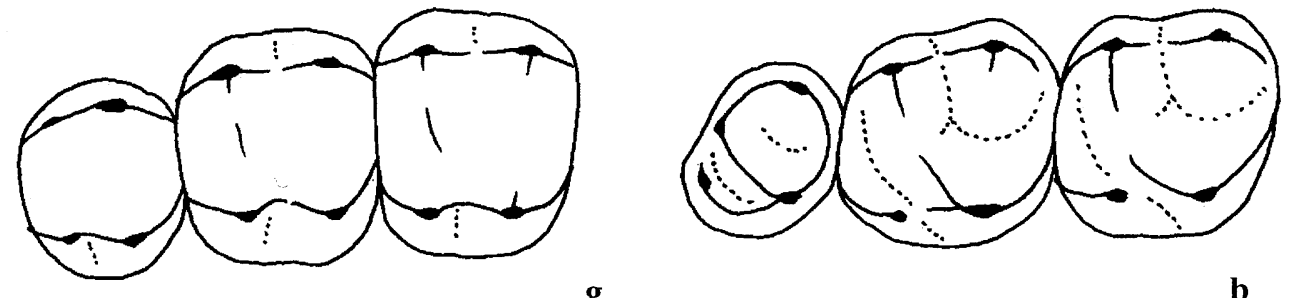

g

b

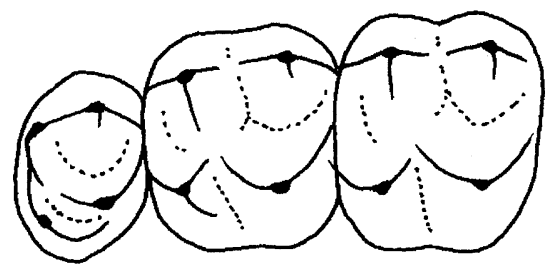

$\mathbf{h}$
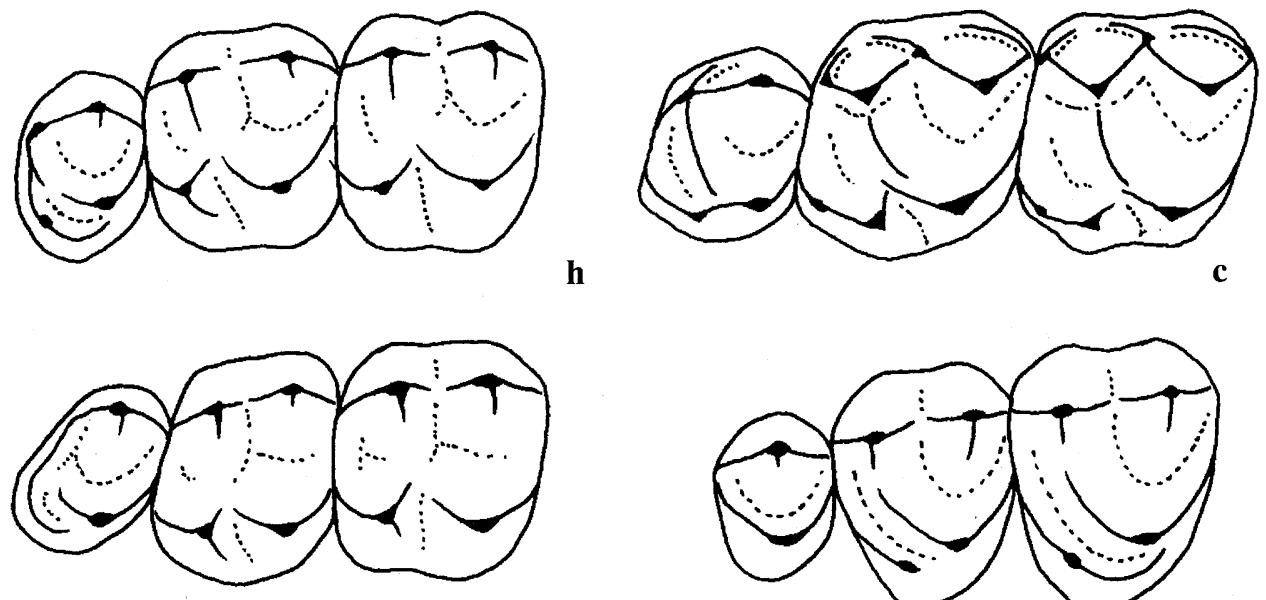

i
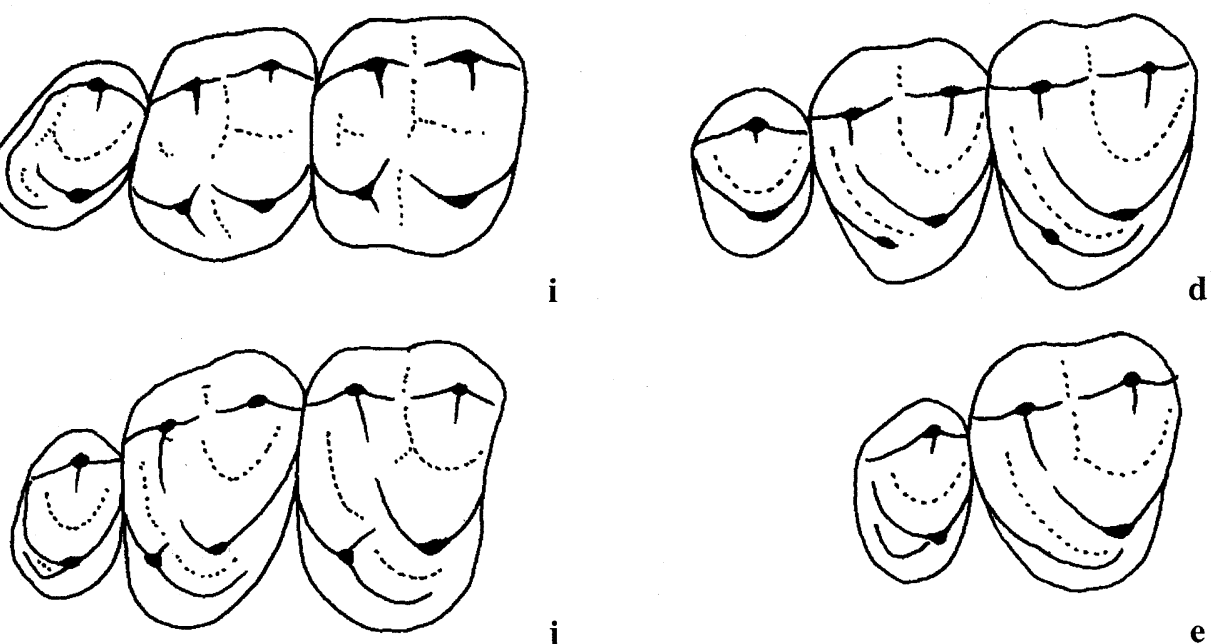

e

Figure 6. The right $\mathrm{M}^{2}$ of Miocallicebus (a, the slanting lines indicate an exposure of dentine area) in comparison with schematic drawings of the upper molars of extant platyrrhines (b, Ateles; c, Alouatta; d, Callimico; e, Saguinus; f, Callicebus; g, Pithecia; h, Aotus; i, Cebus; j, Saimiri). Not same scale. 
anterior portion is much wider buccolingually than the posterior one. Thus, the middle Miocene species of Aotus definitely differs from Miocallicebus in $\mathrm{M}^{2}$ structure.

In extant pitheciines upper molars have minute enamel crenulation and no (or very poorly developed) lingual cingula, and they are usually worn flat, forming a smooth cradle-like wear facet. The $\mathrm{M}^{1}$ and $\mathrm{M}^{2}$ are nearly the same size and $\mathrm{M}^{3}$ is not so small as in Miocallicebus. Also in Cebupithecia, a fossil pitheciine discovered in the La Venta fauna, the $\mathrm{M}^{2}$ has a distinct lingual cingulum and none of the buccal and lingual grooves, and the paracone and metacone are situated buccally as in Miocallicebus (Fig. 5c). The critical difference in $\mathrm{M}^{2}$ structure between Cebupithecia and Miocallicebus is in their wear pattern: as in extant pitheciines, the $\mathrm{M}^{2}$ of Cebupithecia is worn evenly without any distinct dentine exposure, while in Miocallicebus, the $\mathrm{M}^{2}$ is not worn evenly but exposes an island-like dentine area at the protoconehypocone position (Fig. 5a, c).

Miocallicebus is very similar to extant Callicebus in the following features: neither a buccal nor a lingual groove is present on $\mathrm{M}^{2}$; a distinct lingual cingulum is present on $\mathrm{M}^{2}$; the paracone and metacone are rather buccally situated; $\mathrm{M}^{1}$ is slightly larger than $\mathrm{M}^{2}$ and $\mathrm{M}^{3}$ is much smaller than $\mathrm{M}^{1,2}$; the outline of $\mathrm{M}^{2}$ is nearly square (or slightly wider buccolingually); on $\mathrm{M}^{2}$ the lingual portion (the protocone and hypocone) is worn more rapidly to make a greater dentine exposure than in the buccal portion (Fig. 5a, d). Therefore, considering the $\mathrm{M}^{2}$ morphology of a contemporary fossil aotine (IGM-KU 98003) and pitheciine (Cebupithecia), Miocallicebus is likely to be more closely related to the lineage of callicebines than to other platyrrhine lineages, such as aotines, pitheciines, callitrichines and atelines.

There has been very little morphological research on the dentition of Callicebus but Kobayashi (1990) studied morphological variation in upper molars in three species of Callicebus (C. torquatus, C. moloch, and C. personatus). In his opinion, $C$. torquatus shows the most primitive upper molar morphology of the three species: that is, the development of the buccal cingulum, stylar cusps, paraconule, and prehypocrista are weak; the lingual cingulum does not run around the hypocone distolingually but connects to the hypocone directly; and the metaloph (= crista obliqua) is continuous from the protocone to the metacone. This tentative primitive condition of the Callicebus-lineage holds true in Miocallicebus, supporting an ancestor-descendant relationship between Miocallicebus and extant Callicebus and a sister group relationship between the callicebinae and pitheciinae.

MacPhee et al. (1995) discussed the systematic position of Antillothrix bernensis (former name is "Saimiri" bernensis; MacPhee and Wood, 1982; Ford, 1990) and Paralouatta varonai (Rivero and Arredondo, 1991), both of which are Pleistocene fossil taxa from the Antillean islands, using parsimony analysis of 32 craniodental characters, and linked them to extant Callicebus. However, in the $\mathrm{M}^{2}$ of Antillothrix 
the occlusal outline is not rectangular but rather oval; a nearly complete lingual cingulum is strongly developed but the hypocone is absent; and the paracone and metacone are not situated as buccally as in Miocallicebus. In Paralouatta, on the other hand, although the hypocone is present on the well-developed lingual cingulum, the protocone is situated much more buccally than the hypocone. Miocallicebus is likely to be more similar to extant Callicebus than to these Caribbean taxa in $\mathrm{M}^{2}$ structure.

\section{Position of the Pterygoid Process}

In Miocallicebus the base of the pterygoid process is situated much more medially than the lingual marginal line of the upper molars, protruding posteriorly from the position distolingual to M3 (Fig. 2). Among extant platyrrhines, although the position of the pterygoid process relative to the upper dentition line shows various patterns (Table 1), in callitrichines, Saimiri and Ateles the base of the pterygoid process is obviously situated medial to the lingual marginal line of the upper dentition as in Miocallicebus. Particularly in Saimiri and Ateles the base of the pterygoid process is separated from the alveolar process by a deep palatine groove or palatine foramen. In callitrichines, however, the position of the pterygoid process is likely to be influenced by the reduction of the alveolar process and $\mathrm{M}^{3}$, indicating a substantial difference from Saimiri and Ateles in the pattern of the structure of the pterygoid process.

In other platyrrhines the position of the base of the pterygoid process is slightly medial to the lingual marginal line (Callicebus, Chiropotes, Brachyteles and Alouatta) or on the line of the upper molars (Pithecia, Cacajao, Lagothrix, Cebus, and Aotus). In Callicebus, a palatine foramen is located rather anteriorly, medial to $\mathrm{M}^{2}$, so the diastema between the pterygoid process and the marginal line of the upper dentition

Table 1. Position of the pterygoid process relative to the marginal line of upper tooth row in Miocallicebus and extant platyrrhines

\begin{tabular}{ccc}
\hline medial & slightly medial & on the line \\
\hline Cebuella & Chiropotes & Pithecia \\
Callithrix & Alouatta & Cacajao \\
Saguinus & Brachyteles & Lagothrix \\
Leontopithecus & Callicebus & Cebus \\
Callimico & & Aotus \\
Saimiri & & Paralouatta \\
Ateles & & \\
Miocallicebus & & \\
\hline
\end{tabular}


is very narrow. In Paralouatta, which MacPhee et al. (1995) regarded as the sister group of Callicebus, the pterygoid process seems to be positioned on the extended line of the lingual margin of the upper molars (Rivero and Arredondo, 1991). In Cebupithecia (UCMP 38762) the posterior part of the palatine is also preserved: although in this specimen the base of the pterygoid process is unfortunately broken off, a distinct deep palatine groove is observed at the posterior end of the palatine, suggesting a rather medial position of the pterygoid process.

The position of the pterygoid process of Miocallicebus suggests the presence of a relatively deep palatine groove between the alveolar process and the pterygoid process, which is different from the pattern in extant Callicebus.

\section{Comparisons with Fossil Platyrrhines from Patagonia and Chile}

Several researchers have pointed out the dental resemblance between extant Callicebus and Carlocebus, an early-middle Miocene form from Patagonia (Fleagle, 1990, 1999; Fleagle et al., 1997; also see Fleagle et al., 1987), suggesting a possible phyletic relationship between them. Indeed, in Carlocebus $\mathrm{M}^{2}$ has a rectangular outline with a large hypocone on the distinct lingual cingulum as in Callicebus. These features are also observed on $\mathrm{M}^{2}$ of Chilecebus, an early Miocene form from central Chile (Flynn et al., 1995). However, Carlocebus and Chilecebus differ from Callicebus and Miocallicebus in that the paracone and metacone are not buccally situated and $\mathrm{M}^{2}$ is buccolingually wide rather than it is mesiodistally long. A large cingulum-derived hypocone on $\mathrm{M}^{2}$ is observed not only in Carlocebus, Chilecebus and Callicebus but also in other early/middle Miocene southern South American forms, such as Dolichocebus and Soriacebus (Fleagle, 1990), suggesting that this feature is not a shared derived character of certain taxa but is a primitive state in early platyrrhines. Although some more fossil platyrrhines, such as Homunculus, Tremacebus and Proteropithecia, have been discovered from the early-middle Miocene sediments in Patagonia (Bluntschili, 1931; Hershkovitz, 1970; Tauber, 1991; Fleagle and Bown, 1983; Kay et al., 1998), the upper molars of these genera are preserved so poorly (or unknown) that it is impossible to compare them with Miocallicebus.

\section{Phyletic Position of the Callicebines}

The phyletic position of Callicebus among the extant platyrrhines has been disputed by many researchers (e.g. Rosenberger, 1981; Ford, 1986; Kay, 1990; Schneider et al., 1993; Harada et al., 1995; Porter et al., 1995; Porter et al., 1997a, 1997b; Barroso et al., 1997). Among morphological studies, Rosenberger (1981) proposed the Aotus-Callicebus clade, which was considered to be closely related to the pitheciines; Ford (1986) regarded the Callicebus-Aotus clade as closely related not to the 
pitheciines but probably to Saimiri; and Kay (1990) considered that Callicebus is the most primitive lineage among the extant platyrrhine clade. Thus, the results of three morphological studies on the phyletic position of Callicebus are not consistent with each other. Is Callicebus most closely related to Aotus or to the pitheciines?

As already discussed above, Miocallicebus and Cebupithecia are more similar to each other in $\mathrm{M}^{2}$ structure than to a fossil aotine from the La Venta (IGM-KU 98003): Miocallicebus and Cebupithecia share a distinct lingual cingulum on $\mathbf{M}^{2}$, whereas a fossil aotine obviously lacks the lingual cingulum but retains a rather deep lingual sulcus, showing a strong resemblance to extant Aotus (Setoguchi and Rosenberger, 1987). In the La Venta fauna, therefore, the Aotus lineage seems to have split off from the Callicebus lineage much earlier than when the pitheciine clade diverged from the Callicebus lineage.

Recent many molecular biological studies support the Callicebus-pitheciine clade, linking Aotus not to Callicebus but to the Cebus-Saimiri and/or callitrichine clade. Schneider et al. (1993), Porter et al. (1995), and Porter et al. (1997a, b) proposed the Callicebus-pitheciine clade using $\mathcal{E}$-globin gene sequences. Harada et al. (1995) and Barrosa et al. (1997) support the Callicebus-pitheciine clade having analyzed the interstitial reinol-binding protein nuclear gene sequences (IRBP). The concurrence of these analyses based on two different gene sequences reinforces the reliability of the Callicebus-pitheciine clade.

Further, Horovitz et al. (1998) and Horovitz (1999) proposed phylogenetic trees of extant and extinct platyrrhines by analyzing morphological characters and nuclear (IRBP and $\varepsilon$-globin) and mitochondrial (12S and partial $16 \mathrm{~S}$ ) gene sequences. Although in their previous studies using $12 \mathrm{~S}$ and $16 \mathrm{~S}$ mitochondrial gene sequences Callicebus was not most closely related to the pitheciine clade, the simultaneous analysis of mitochondrial and nuclear genes and morphological characters supported a Callicebus-pitheciine clade (Horovitz et al., 1998; Horovitz, 1999).

On the other hand, the $\mathrm{M}^{2}$ structure of Antillothrix and Paralouatta, both of which were discovered from the Pleistocene of the Caribbean islands and are considered closely related to the callicebinae, is unlikely to support this hypothesis (MacPhee et al., 1995). Neither of them shows an "intermediate" $\mathrm{M}^{2}$ morphology between Miocallicebus and extant Callicebus. In fact, they are less similar to Callicebus than is Miocallicebus, at least in $\mathrm{M}^{2}$ structure. In Antillothrix, $\mathrm{M}^{2}$ is much reduced compared to $\mathrm{M}^{1}$ : the occlusal outline is oval in shape rather than rectangular, and the hypocone is indistinct. In Paralouatta the lingual cingulum is so developed that the protocone is situated much more buccally than the hypocone. The $\mathrm{M}^{2}$ morphology does not support a Miocallicebus-Antillothrix/Paralouatta-Callicebus lineage, which is the most simple ancestor-descendant relationship hypothesis. 


\section{Divergence Time of Callicebines in Relation to Other Platyrrhine Clades}

Recently, several molecular biological studies have estimated the divergence dates among platyrrhine lineages (Table 2, Schneider et al., 1993; Porter et al., 1997a,b; Barroso et al., 1997). In these studies, although the estimated divergence dates of each node differ somewhat, there is no serious inconsistency among them (Table 2). For instance, the divergence time of Callicebus and the pitheciines is estimated as 14.5 Ma by using the $\varepsilon$-globin gene (Schneider et al., 1993; Porter et al., 1997a), 16.2 Ma by the IRBP gene (Barroso et al., 1997), and 15.2 Ma with the combined data of IRBP and $\mathcal{\varepsilon}$-globin (Barroso et al., 1997). So, here we adopt the estimation dates (15.2 Ma) by Barroso et al. (1997), which used the combined data of the IRBP and eglobin gene (Fig. 7).

As already mentioned, radioisotopic dates of the La Venta sediments have been reported by some workers. Takemura et al. (1992) reported three fission-track dates $(12.6 \pm 0.5,13.6 \pm 0.7$, and $13.6 \pm 0.5 \mathrm{Ma})$ from the upper part of the Tatacoa Red Member of the Villavieja Formation (Fig. 2), and Gurrero (1997) and Flynn et al. (1997) concluded that the age of the sediments of the La Victoria and Villavieja Formations are about 13.5-12.9 Ma and 12.9-11.5 Ma, respectively, based on a combination of paleomagnetic stratigraphy and ${ }^{40} \mathrm{Ar} /{ }^{39} \mathrm{Ar}$ dates. There is no substantial difference between the estimations by these two research groups: that is, the sediments of La Venta badlands producing many platyrrhine fossils were deposited during 13.5-11.5 Ma. Accordingly, the absolute age of the La Venta primates can be estimated as about $13 \mathrm{Ma}$. The estimated divergence date for Callicebus-pitheciines (15.2 Ma) is older than the absolute age for the La Venta sediments (13 Ma), so there is no contradiction between these two estimations (Fig. 7).

Table 2. Estimated divergence time of several platyrrhine clades based on molecular clock calculations. A reference date of $35 \mathrm{Ma}$ for the platyrrhine-catarrhine divergence, which is based on the paleontological studies, was used in these studies. The Cebidae includes Cebus, Saimiri, Aotus and the Callitrichinae. The Atelidae includes the Atelinae, Pitheciincae and Callicebus.

\begin{tabular}{lcccc}
\hline Clade & $\begin{array}{c}\text { Schneider et al. } \\
(1993)\end{array}$ & $\begin{array}{c}\text { Porter et al. } \\
(1997 \mathrm{a})\end{array}$ & $\begin{array}{c}\text { Porter et al. } \\
(1997 \mathrm{~b})\end{array}$ & $\begin{array}{c}\text { Barroso et al. } \\
(1997)\end{array}$ \\
\hline Cebidae-Atelidae & 20.1 & 22.7 & 21.3 & 21.3 \\
Atelinae-Pitheciinae & 17.0 & & & \\
Callicebus-Pitheciinae & 14.5 & & 14.5 & 15.2 \\
Atelinae & & & & 13.7 \\
Saimiri-Cebus-Aotus-Callitrichinae & 17.7 & & & \\
Saimiri-Cebus & & 17.0 & 16.3 & 16.7 \\
Aotus-Callitrichinae & & 17.9 & 16.7 & 17.5 \\
\hline
\end{tabular}




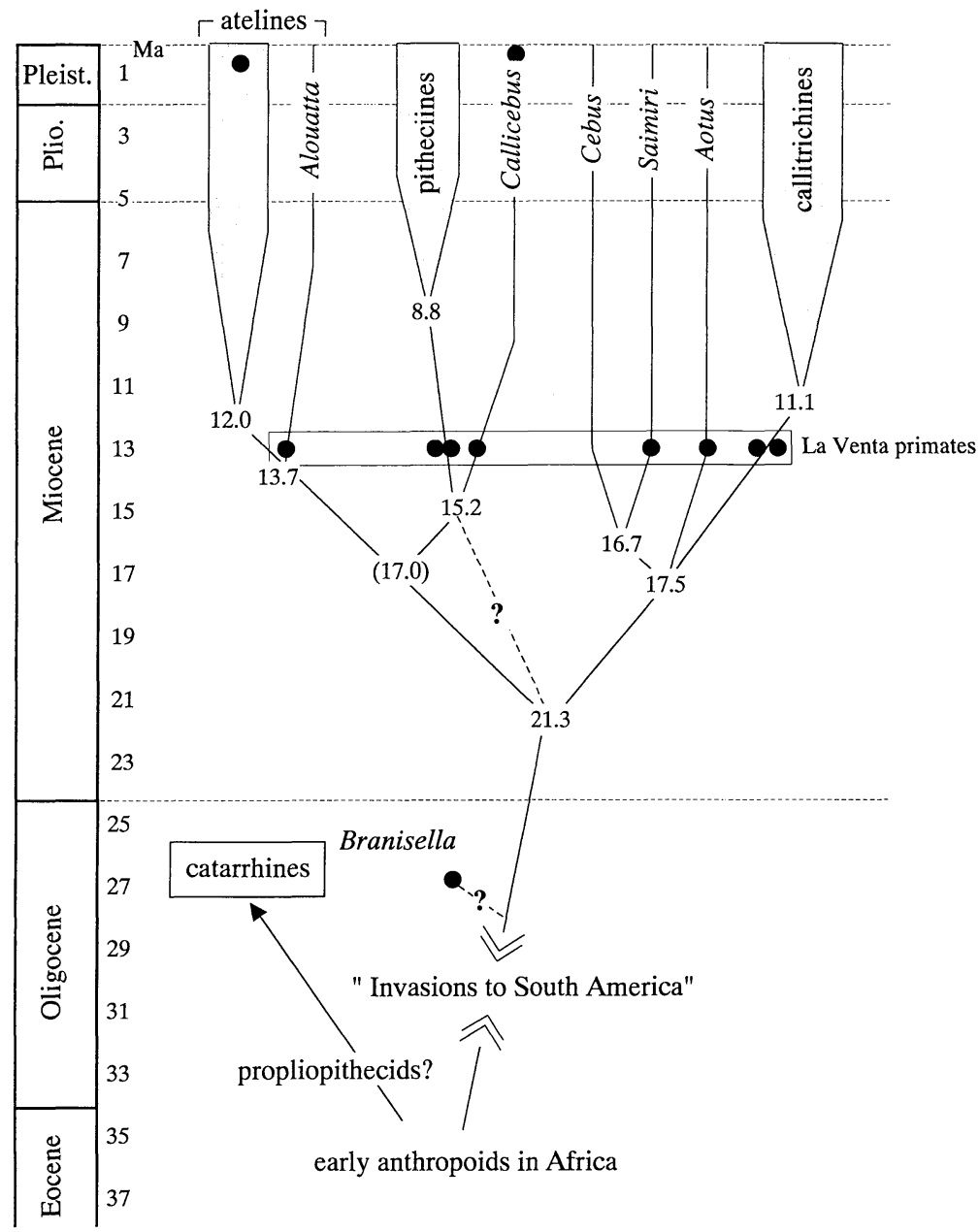

Figure 7. A hypothetical phylogenetic tree of platyrrhine monkeys mainly based on the molecular analysis by Barroso et al. (1997). Numbers at the main nodes, such as 21.3, are the estimated divergence time between lineages (see Table 2 for more detailed data). Filled circles indicate fossil taxa discovered in the La Venta fauna.

As for estimations on other divergence times, however, there seem to be some problems. Fig. 7 shows a schematic phylogenetic tree of extant platyrrhines reconstructed by these molecular studies, indicating the divergence times of some important nodes proposed by Barroso et al. (1997) and the geological ages of La Venta primates and Branisella (filled circles). As mentioned in the introduction, fossil taxa of most extant platyrrhine lineages have been discovered in the La Venta fauna: Stirtonia for the Alouatta lineage, Cebupithecia and Nuciruptor for the pitheciines, Neosaimiri for Saimiri, Aotus dindensis (and/or Mohanamico?) for extant Aotus, 
Micodon and Lagonimico for the callitrichines. All estimations of the divergence times of these lineages (13.7 Ma for atelines, 15.2 Ma for Callicebus-pitheciines, 16.7 Ma for Cebus-Saimiri, and 17.5 Ma for Aotus-callitrichines) are older than the age of the La Venta primates (13 Ma).

However, the strong dental resemblance, that is a specialization to a folivorous diet, between Stirtonia (fossil taxon) and Alouatta (extant taxon) suggest that the Alouatta lineage might have diverged much earlier than 13.7 Ma. Moreover, if the estimated divergence time for extant platyrrhines is actually $21.3 \mathrm{Ma}$, Branisella, the oldest fossil platyrrhine discovered from the latest Oligocene of Bolivia (about 26$27 \mathrm{Ma}$, MacFadden et al., 1985; Kay et al., 1998), should be excluded from the extant platyrrhine clade. Although the phyletic position of Branisella has not yet been well established, several researchers have pointed out the resemblance between Branisella and callitrichine monkeys (Rosenberger et al., 1991; Takai and Anaya, 1996; Takai et al., 2000). The estimated divergence dates for platyrrhine clades seem to be too young for the estimations based on fossil records. More complete fossil materials of Miocallicebus would shed more light on the phylogenetic study of platyrrhine monkeys.

\section{Acknowledgments}

We thank all staff of INGEOMINAS of Colombia for their cooperation and support for our fieldwork since 1977 in the Tatacoa Desert. We are very grateful to Dr. Arnol Tovar E. of Instituto Huilense de Cultura, Huila Department, Colombia for the organization of our research at Villavieja village. We also thank Dr. Richard Kay of Duke University and Dr. Patricia Holroyd of the Museum of Paleontology, University of California, Berkeley, for kindly showing us the fossil specimens of La Venta. For access to skeletal specimens of New World monkeys under their care, we thank Drs. Bruce Patterson and Bill Stanley of the Field Museum of Natural History (Chicago) and Guy Musser and Wolfgang Fuchs of the American Museum of Natural History (New York). This work was supported by Overseas Scientific Research Funds (No. 10041165) and partly by Grant-in-Aid for COE Research (No. 10CE2005) from the Ministry of Education, Science and Culture.

\section{References}

Barroso C.M.L., Schneider H., Schneider M.P.C., Sampaio I., Harada M. L., Czelusniak J., and Goodman M. (1997) Update on the phylogenetic systematics of New World monkeys: further DNA evidence for placing the pygmy marmoset (Cebuella) within the genus Callithrix. Int. J. Primatol., 18 (4): 651-674.

Bluntschili H. (1931) Homunculus patagonicus und die ihm zugereihten Fossil funde aus den Santa- 
Cruz-Schichten Patagoniens. Morphol. Jahrb., 67: 811-892.

Fleagle J. G. (1990) New fossil platyrrhines from the Pinturas Formation, southern Argentina. J. Hum. Evol., 19: 61-85.

Fleagle J. G. and Bown T. M. (1983) New Primate Fossils from Late Oligocene (Colhuehuapian) Localities of Chubut Province Argentina. Folia Primatol., 41: 240-266.

Fleagle J. G. and Kay R. F. (1997) Platyrrhines, catarrhines, and the fossil record. In: Kinzey W. G. (ed.), "New World Primates: Ecology, Evolution, and Behavior," Walter de Gruyter, Inc., New York, pp. 3-23.

Fleagle J. G. (1999) Primate Adaptation and Evolution. Academic Press, San Diego.

Fleagle J. G., Powers D. W., Conroy G. C., and Watters J. P. (1987) New fossil platyrrhines from Santa Cruz Province, Argentina. Folia Primatol., 48: 65-77.

Fleagle J. G., Kay R. F., and Anthony M. R. (1997) Fossil New World monkeys. In: Kay R. F., Madden R. H., Ciffeli R. L., and Flynn J. L. (eds.), "Vertebrate Paleontology in the Neotropics: The Miocene Fauna of La Venta, Colombia," Smithsonian Institution Press, Washington D.C., pp. 473-495.

Flynn J. J., Guerrero J., Swisher III C. C. (1997) Geochronology of the Honda Group. In: Kay R. F., Madden R. H., Ciffeli R. L., and Flynn J. L. (eds.), "Vertebrate Paleontology in the Neotropics: The Miocene Fauna of La Venta, Colombia," Smithsonian Institution Press, Washington D.C., pp. 44-59.

Flynn J. J., Wyss A.R., Charrier R., and Swisher C. (1995) An Early Miocene anthropoid skull from the Chilean Andes. Nature., 373: 603-607.

Ford S. M. (1986) Systematics of the New World monkeys. In: Swindler D. R. and Erwin J. (eds.), "Comparative Primate biology, vol. 1: Systematics, Evolution, and Anatomy," Alan R. Liss, New York, pp. 73-135.

Ford S. M. (1990) Platyrrhine evolution in the West Indies. J. Hum. Evol., 19: 237-254.

Guerrero J. (1997) Stratigraphy, sedimentary environments, and the Miocene uplift of the Colombian Andes. In: Kay R. F. et al. (eds.), "Vertebrate Paleontology in the Neotropics," pp. 15-43.

Harada M. L., Schneider H., Schneider M.P.C., Sampaio I., Czelusniak J., and Goodman M. (1995) DNA evidence on the phylogenetic systematics of New World monkeys: support for the sistergrouping of Cebus and Saimiri from two unlinked Nuclear genes. Mol. Phylogen. Evol., 4 (3): 331-349.

Hershkovitz P. (1970) Notes on Tertiary platyrrhine monkeys and description of a new genus from the late Miocene of Colombia. Folia Primatol., 12: 1-37.

Horovitz I. (1999) A phylogenetic study of living and fossil platyrrhines. Am. Mus. Novitates., 3269: $1-40$.

Horovitz I. and Meyer A. (1995) Systematics of New World Monkeys (Platyrrhini, Primates) based on $16 \mathrm{~S}$ mitochondrial DNA sequences: a comparative analysis of different weighting methods in cladistic analysis. Mol. Phyl. Evol., 4 (4): 448-456.

Horovitz I., Zardoya R., and Meywe A. (1998) Platyrrhines systematics: a simultaneous analysis of molecular and morphological data. Am. J. Phys. Anthropol., 106: 261-281.

Kay R. F. (1990) The phyletic relationships of extant and fossil Pitheciinae (Platyrrhini, Anthropoidea). J. Hum. Evol., 19: 175-208.

Kay R. F. (1994) "Giant” Tamarin from the Miocene of Colombia. Am. J. Phys. Anthropol., 95: 333353.

Kay R. F. and Meldrum J. (1997) A new small platyrrhine and the phyletic position of callitrichinae. In: Kay R. F., Madden R. H., Ciffeli R. L., and Flynn J. L. (eds.), "Vertebrate Paleontology in the 
Neotropics: The Miocene Fauna of La Venta, Colombia," Smithsonian Institution Press, Washington D.C., pp. 435-458.

Kay R. F., MacFadden B. J., Madden R. H., Sandeman H., and Anaya F. (1998) Revised age of the Salla beds, Bolivia, and its bearing on the age of the Deseadan South American Land Mammal “Age". J. Vert. Paleontol., 18 (1): 189-199.

Kay R. F., Madden R. H., Plaven J. M., Cifelli R. L., and Guerrero. J. (1987) Stirtonia victoriae, a new species of Miocene Colombian primate. J. Hum. Evol.. 16, 173-196.

Kobayashi S. (1990) A morphological study of upper first and second molars in the genus Callicebus. J. Anthropol. Soc. Nippon., 98 (2): 121-135.

Luchterhand K., Kay R. F., and Madden R. H. (1986) Mohanamico hershkovitzi, gen et sp. nov., un primate du Miocène moyen d'Amérique du Sud. C. R. Acad. Sc. Paris. 303, Série II: 1753-1758.

MacFadden B. J., Campbell-Jr. K. E., Cifelli R. L., Siles O., Johnson N. M., Naeser C. W., and Zeitler P. K. (1985) Magnetic polarity stratigraphy and mammalian fauna of the Deseadan (Late Oligocene-Early Miocene) Salla beds of northern Bolivia. J. Geology., 93: 223-250.

MacPhee R.D.E., Horovitz I., Arredondo O., and Vasquez O. J. (1995) A new genus for the extinct Hispaniolan monkey Saimiri bernensis Rímoli, 1977, with notes on its systematic position. Am. Mus. Novitates., 3134: 1-21.

MacPhee R.D.E. and Wood C. A. (1982) A new fossil cebine from Hispaniola. Am. J. Phys. Anthropol., 58: 419-436.

Madden R. H., Guerrero J., Kay R. F., Flynn J. J., Swisher III C. C., and Walton A. (1996) The Laventan stage and age. In: Kay R. F. et al. (eds.), "Vertebrate Paleontology in the Neotropics: the Miocene fauna of La Venta, Colombia," Smithsonian Institute Press, Washington D.C., pp. 499519.

Meldrum J. and Kay R. F. (1997) Nuciruptor rubricae, a new pitheciine seed predator from the Miocene of Colombia. Am. J. Phys. Anthropol., 102: 407-427.

Nakatsukasa M., Takai M., and Setoguchi T. (1997) Functional morphology of the postcranium and locomotor behavior of Neosaimiri fieldsi, a Saimiri-like Middle Miocene platyrrhine. Am. J. Phys. Anthropol., 102: 515-544.

Porter C. A., Czelusniak J., Schneider H., Schneider M.P.C., Sampaio I., and Goodman M. (1997a) Sequences of the primate $\varepsilon$-globin gene: implications for systematics of the marmosets and other New World primates. Gene, 205: 59-71.

Porter C. A., Page S. L., Czelusniak J., Schneider H., Schneider M.P.C., Sampaio I., and Goodman M. (1997b) Phylogeny and evolution of selected primates as determined by sequences of the $\varepsilon$-globin locus and 5' flanking regions. Int. J. Primatol., 18 (2): 261-295.

Porter C. A., Sampaio I., Schneider H., Schneider M.P.C., Czelusniak J., and Goodman M. (1995) Evidence on primate phylogeny from $\varepsilon$-globin gene sequences and flanking regions. J. Mol. Evol., 40: $30-55$.

Rivero M. and Arredondo O. (1991) Paralouatta varonai, a new Quaternary platyrrhine from Cuba. J. Hum. Evol., 21: 1-11.

Rosenberger A. L. (1979) Phylogeny, evolution and classification of New World monkeys (Platyrrhini, Primates). Ph.D. thesis of City Univ. New York.

Rosenberger A. L. (1981) Systematics: The higher taxa. In: Coimbra-Filho A. F. and Mittermeier R. A. (eds.), "Ecology and Behavior of Neotropical Primates," Academia Braseliera de Ciencias, Rio de Janeiro, pp. 9-27.

Rosenberger A. L., Setoguchi T., and Hartwig W. C. (1991): Laventiana annectens, new genus and species: fossil evidence for the origins of callitrichine New World monkeys. Proc. Natl. Acad. Sci. 
USA, 88: 2137-2140.

Rosenberger A. L., Setoguchi T., and Shigehara N. (1990) The fossil records of callitrichine primates. J. Hum. Evol., 19: 209-236.

Schneider H., Schneider M.P.C., Sampaio I., Harada M. L., Stanhope M., Czelusniak J., and Goodman M. (1993) Molecular phylogeny of the New World monkeys (Platyrrhini, Primates). Molecular Phylogenetics and Evolution., 2 (3): 225-242.

Setoguchi T. and Rosenberger A. L. (1985) Miocene Marmosets: First Fossil Evidence. Int. J. Primatol., $6(6): 615-625$.

Setoguchi T. and Rosenberger A. L. (1987) A fossil owl monkey from La Venta, Colombia. Nature, 326: 629-694.

Setoguchi T., Watanabe T., and Mouri T. (1981) The upper dentition of Stirtonia (Ceboidea, Primates) from the Miocene of Colombia, South America, and the origin of the postero-internal cusps of upper molars of howler monkeys (Alouatta). Kyoto Univ. Overseas Reports of New World Monkeys., 3: 51-60.

Stirton R. A. (1951) Ceboid monkeys from the Miocene of Colombia. Bull. Univ. Calif. Publ. Geo. Sci., 28: 315-335.

Takai M. (1994) New specimens of Neosaimiri fieldsi from La Venta, Colombia: a middle Miocene ancestor of the living squirrel monkeys. J. Hum. Evol., 27: 329-360.

Takai M. and Anaya F. (1996) New specimens of the oldest fossil platyrrhine, Branisella boliviana, from Salla, Bolivia. Am. J. Phys. Anthropol., 99: 301-317.

Takai M., Anaya F., Shigehara N., and Setoguchi T. (2000) New fossil materials of the earliest New World monkey, Branisella boliviana, and the problem of platyrrhine origins. Am. J. Physical Anthropol., 111: 263-281.

Takai M., Takemura K., Takemura A., Villarroel C., Hayashida A., Danhara T., Ohno T., Franco R., Setoguchi T., and Nogami Y. (1992) Geology of La Venta, Colombia, South America. Kyoto Univ. Overseas Res. Rep. of New World Monkeys, 8: 1-17.

Takemura A., Takai M., Danhara T., and Setoguchi T. (1992) Fission-track ages of the Villavieja Formation of the Miocene Honda Group in La Venta, Department of Huila, Colombia. Kyoto Univ. Overseas Res. Rep. of New World Monkeys, 8: 19-27.

Tauber A. (1991) Homunculus patagonicus Ameghino, 1891 (Primates, Ceboidea), Mioceno Temprano, de la Costa Atlantica Austral, Prov. de Santa Cruz, Republica Argentina. Acad. Nac. Ciencias Misc., 82: 1-32.

Editor-in-Charge: Yuji Mizoguchi 